\title{
The content of chromium and copper in plants and soil fertilized with sewage sludge with addition of various amounts of $\mathrm{CaO}$ and lignite ash
}

\begin{abstract}
The influence of fertilization with fresh sewage sludge with the addition of calcium oxide and lignite ash in the proportions dry mass $6: 1,4: 1,3: 1$ and 2:1 on the content of chromium and copper in plants and soil and uptake of these elements was investigated in pot experiment. Sewage sludge were taken from Siedlce (sludge after methane fermentation) and Łuków (sludge stabilized in oxygenic conditions), eastern Poland. The chromium content in the biomass of the test plants (maize, sunflower and oat) was higher following the application of mixtures of sewage sludge with ash than of the mixtures with CaO. The copper content in plants most often did not significantly depend on the type of additives to the sludge. Various amounts of additives to the sewage sludge did not have a significant effect on the contents of either of the studied trace elements in plants. The contents of chromium and copper in soil after 3 years of cultivation of plants were higher than before the experiment, but these amounts were not significantly differentiated depending on the type and the amount of the used additive (i.e. $\mathrm{CaO}$ vs. ash) to sewage sludge.
\end{abstract}

Keywords: sewage sludge, calcium oxide, lignite ash, chromium, copper

\section{INTRODUCTION}

Land application of sewage sludge is one of the best and most popular disposal alternatives of sludge due to possibility to bring organic matter, nitrogen, phosphorus and micronutrients to the soil. These wastes generally are a substances of differing properties. They may contain components of a fertilizer, but also environmental contaminants (Singh and Agrawal 2008, Usman et al. 2012, Tiruneh et al. 2014, Wierzbowska et al. 2016). One of the harmful chemicals accumulated in the soil and that way incorporated into the nutrition chain are trace elements (Sanerbeck 1991, Hooda and Alloway 1994). The level of plant uptake, bio-accumulation and tolerance of plants to heavy metals varies among different crops at different rates of application of sewage sludge (Yilmaz and Temizgul 2012). Risk of contamination in the environment is observed through leaching of heavy metals from soils to groundwater. The risk increases with time as metals are persistent in soils over a longer time and many metals do not undergo bio-chemical degradation thereby increasing the risk of bio-availability of metals and their leaching to groundwater table (Gadepalle et al. 2008). Heavy metal content in the sewage sludge depends on the type of purified sewage, as well as its separation, concentration, and stabilization methods. Their content is often not stable, and the coefficient of variation for some of them is more than 100\% (Grzywnowicz and Strutyński 2000, Czekała et al. 2002). Factors influencing significantly the availability of heavy metals to plants and their accumulation in the soil is $\mathrm{pH}$ of both sludge and soil (Smith 1996). Usually, only a small part of the total heavy metals contents occurs in a form of mobile fractions, but they most often form stable chemical bindings or complexes that are biologically almost inactive (Jakubus and Czekała 2001). Stabilizing the sludge using lime and lignite ash, which contains heavy metals, leads most often to diluting the heavy metals concentrations and increasing the percentage of easy-available forms for plants along with the increase of organic matter mineralization rates resulting in creation of mobile forms of metals (Rosik-Dulewska 2000, 2001; Basu et al. 2009).

The aim of present study was to assess the influence of sewage sludge fertilization with addition of different amounts of $\mathrm{CaO}$ and lignite ash on contents and uptake of chromium and copper by test plants (maize, sunflower and oat), as well as to determine these heavy metal concentrations in the soil after three-year experiment was completed. 


\section{MATERIALS AND METHODS}

Sewage sludge from a sewage treatment plant in Siedlce (after methane fermentation) and from Łuków (stabilised under aerobic conditions), eastern Poland, were separately mixed with calcium oxide (analytical grade) and with lignite ash in weight ratios of 2:1, $3: 1,4: 1$ and $6: 1$ calculated on the dry matter of the components. The $\mathrm{pH}$ value of the ash was 12.1 and the contents of chromium and copper 74.8 and 39.1 $\mathrm{mg} \cdot \mathrm{kg}^{-1}$ of dry matter (DM), respectively. Sewage sludge from Siedlce (19\% DM) and Łuków (15\% DM) contained 26.8 and $416.3 \mathrm{mg} \cdot \mathrm{kg}^{-1} \mathrm{Cr}$, and 123.7 and $78.7 \mathrm{mg} \cdot \mathrm{kg}^{-1} \mathrm{Cu}$, respectively, in the dry matter.

The prepared mixtures and the sludge without additions, in amounts of $0.8 \mathrm{~kg}$, were put into pots containing $8 \mathrm{~kg}$ of soil. In the experiment, control objects were selected where organic fertilisation was not applied (Table 1). They included cultivation of plants on unfertilised soil and on soil with an addition of $\mathrm{CaO}$ and of lignite ash in amounts corresponding to their average masses introduced in the mixtures (53 g per pot). A detailed diagram of the pot culture experiment performed in 3 repetitions in a glasshouse, is presented in Table 1 .

Sewage sludge and their mixtures were used in single doses only in the first year (10 days before the seeds were sown), whereas the after-effect was studied in the second and third years. Because of the low potassium contents in the sludge and their mixtures,

TABLE 1. Scheme of the pot experiment

\begin{tabular}{|c|c|c|}
\hline \multicolumn{3}{|c|}{ Kind of fertilization } \\
\hline \multicolumn{3}{|c|}{$\begin{array}{l}\text { Soil material - control object } \\
\text { Soil fertilized with } \mathrm{CaO} \\
\text { Soil fertilized with the ash }\end{array}$} \\
\hline \multirow{3}{*}{$\begin{array}{l}\text { Sewage sludge } \\
\text { from Siedlce }\end{array}$} & \multicolumn{2}{|l|}{ without addition } \\
\hline & with $\mathrm{CaO}$ addition & $\begin{array}{l}6: 1^{*} \\
4: 1^{*} \\
3: 1^{*} \\
2: 1^{*}\end{array}$ \\
\hline & with lignite ash addition & $\begin{array}{l}6: 1^{*} \\
4: 1^{*} \\
3: 1^{*} \\
2: 1^{*}\end{array}$ \\
\hline \multirow{3}{*}{$\begin{array}{l}\text { Sewage sludge } \\
\text { from Łuków }\end{array}$} & without addition & \\
\hline & with $\mathrm{CaO}$ addition & $\begin{array}{l}6: 1^{*} \\
4: 1^{*} \\
3: 1^{*} \\
2: 1^{*}\end{array}$ \\
\hline & with lignite ash addition & $\begin{array}{l}6: 1^{*} \\
4: 1^{*} \\
3: 1^{*} \\
2: 1^{*}\end{array}$ \\
\hline
\end{tabular}

\footnotetext{
* weight relation between sludge and addition.
}

and the possibility of phosphorus retrogradation on the objects with $\mathrm{CaO}$, pre-sowing supplementary fertilisation with phosphorus and potassium in amounts of $0.44 \mathrm{~g} \mathrm{P}$ (triple granulated superphosphate $-20 \%$ $\mathrm{P})$ and $1.0 \mathrm{~g} \mathrm{~K}$ per pot (potassium sulphate $-49.8 \%$ $\mathrm{K})$ was applied to all objects each year of the experiment.

The test plants in the first and the third year of the experiment were maize (a plant tolerating elevated chromium contents) and forage sunflower (susceptible to copper deficiency) sown following maize harvest in the same pots. In the second year of the experiment, oat (susceptible to elevated chromium content and to copper deficiency) and maize were cultivated. The aboveground parts of the cultivated plants were harvested 80 days after vegetation.

The soil used in the experiment, with granulometric compositions of loamy sand (according to Polish Soil Classification 2011), had slightly acidic reaction ( $\mathrm{pH}$ in $\mathrm{KCl} 1 \mathrm{~mol} \cdot \mathrm{dm}^{-3}$ of 5.4). The contents of organic carbon and total nitrogen in the soil were 6.12 and $0.63 \mathrm{~g} \cdot \mathrm{kg}^{-1}$, respectively.

The contents of chromium and copper in the sewage sludge (Table 2), in the harvested plant material (Tables 3 and 4), and in the soil (Table 5) were determined with the ICP-AES method, in a stock solution obtained after dry mineralisation of the samples at $450^{\circ} \mathrm{C}$.

TABLE 2. The content of chromium and copper in sewage sludge and in their mixtures with $\mathrm{CaO}$ and ash $\left(\mathrm{mg} \cdot \mathrm{kg}^{-1} \mathrm{DM}\right)$, as well as the amounts of these metals corresponding to treatments ( $\mathrm{mg}$ per pot)

\begin{tabular}{|c|c|c|c|c|c|c|}
\hline \multirow{2}{*}{\multicolumn{3}{|c|}{ Kind of fertilization }} & \multicolumn{2}{|c|}{$\begin{array}{l}\text { The content in } \\
\text { sewage sludge }\end{array}$} & \multicolumn{2}{|c|}{$\begin{array}{l}\text { The amount } \\
\text { introduced to soil }\end{array}$} \\
\hline & & & \multirow{2}{*}{$\begin{array}{l}\mathrm{Cr} \\
74.8 \\
\end{array}$} & \multirow{2}{*}{$\begin{array}{l}\mathrm{Cu} \\
39.1 \\
\end{array}$} & \multirow{2}{*}{$\begin{array}{l}\mathrm{Cr} \\
3.97 \\
\end{array}$} & \multirow{2}{*}{$\begin{array}{l}\mathrm{Cu} \\
2.10\end{array}$} \\
\hline Ash & & & & & & \\
\hline \multirow{9}{*}{$\begin{array}{l}\text { Sewage } \\
\text { sludge } \\
\text { from } \\
\text { Siedlce }\end{array}$} & $\begin{array}{l}\text { without } \\
\text { addition }\end{array}$ & & 26.8 & 123.7 & 4.07 & 18.80 \\
\hline & $+\mathrm{CaO}$ & $6: 1$ & 19.3 & 89.2 & 3.95 & 18.23 \\
\hline & & $4: 1$ & 17.0 & 78.3 & 3.89 & 17.95 \\
\hline & & $3: 1$ & 15.1 & 69.7 & 3.83 & 17.68 \\
\hline & & $2: 1$ & 12.4 & 57.3 & 3.72 & 17.17 \\
\hline & + ash & $6: 1$ & 33.7 & 111.6 & 5.79 & 19.19 \\
\hline & & 4:1 & 36.4 & 106.8 & 6.60 & 19.37 \\
\hline & & $3: 1$ & 38.8 & 102.6 & 7.40 & 19.55 \\
\hline & & $2: 1$ & 42.8 & 95.5 & 8.91 & 19.88 \\
\hline \multirow{9}{*}{$\begin{array}{l}\text { Sewage } \\
\text { sludge } \\
\text { from } \\
\text { Łuków }\end{array}$} & \multicolumn{2}{|c|}{ without addition } & 416.3 & 78.7 & 49.96 & 9.44 \\
\hline & \multirow{4}{*}{$+\mathrm{CaO}$} & $6: 1$ & 300.2 & 56.7 & 48.74 & 9.21 \\
\hline & & $4: 1$ & 263.4 & 49.8 & 48.15 & 9.10 \\
\hline & & $3: 1$ & 234.7 & 44.4 & 47.58 & 8.99 \\
\hline & & $2: 1$ & 192.7 & 36.4 & 46.47 & 8.79 \\
\hline & \multirow[t]{4}{*}{+ ash } & $6: 1$ & 367.5 & 73.0 & 50.20 & 9.98 \\
\hline & & $4: 1$ & 348.0 & 70.8 & 50.31 & 10.23 \\
\hline & & 3:1 & 330.9 & 68.8 & 50.43 & 10.48 \\
\hline & & $2: 1$ & 302.5 & 65.5 & 50.65 & 10.97 \\
\hline
\end{tabular}


TABLE 3. The content of chromium in test plants $\left(\mathrm{mg} \cdot \mathrm{kg}^{-1} \mathrm{DM}\right)$

\begin{tabular}{|c|c|c|c|c|c|c|c|c|}
\hline \multicolumn{3}{|c|}{ Kind of fertilization } & \multicolumn{6}{|c|}{ Years of experiment } \\
\hline & & & \multicolumn{2}{|c|}{$1^{\text {st }}$} & \multicolumn{2}{|l|}{$2^{\text {st }}$} & \multicolumn{2}{|l|}{$3^{\text {st }}$} \\
\hline & & & Maize & Sunflower & Maize & Oat & Maize & Sunflower \\
\hline \multirow{3}{*}{\multicolumn{3}{|c|}{$\begin{array}{l}\text { Without fertilization } \\
\mathrm{CaO} \\
\text { Ash }\end{array}$}} & 0.253 & 0.279 & 0.264 & 0.385 & 0.227 & 0.244 \\
\hline & & & 0.274 & 0.272 & 0.233 & 0.391 & 0.209 & 0.250 \\
\hline & & & 0.316 & 0.307 & 0.249 & 0.420 & 0.237 & 0.271 \\
\hline \multirow{2}{*}{\multicolumn{3}{|c|}{$\begin{array}{l}\text { Sewage sludge from Siedlce } \\
\text { Sewage sludge from Łuków }\end{array}$}} & 0.384 & 0.318 & 0.248 & 0.318 & 0.234 & 0.265 \\
\hline & & & 0.696 & 0.554 & 0.467 & 0.625 & 0.485 & 0.438 \\
\hline \multirow{8}{*}{$\begin{array}{l}\text { Sewage } \\
\text { sludge } \\
\text { from Siedlce }\end{array}$} & $+\mathrm{CaO}$ & $6: 1$ & 0.348 & 0.275 & 0.216 & 0.297 & 0.248 & 0.245 \\
\hline & & $4: 1$ & 0.334 & 0.284 & 0.219 & 0.273 & 0.215 & 0.236 \\
\hline & & $3: 1$ & 0.353 & 0.256 & 0.227 & 0.268 & 0.253 & 0.206 \\
\hline & & $2: 1$ & 0.312 & 0.234 & 0.218 & 0.251 & 0.292 & 0.228 \\
\hline & + ash & $6: 1$ & 0.379 & 0.344 & 0.231 & 0.360 & 0.229 & 0.243 \\
\hline & & $4: 1$ & 0.392 & 0.330 & 0.243 & 0.331 & 0.214 & 0.239 \\
\hline & & $3: 1$ & 0.394 & 0.305 & 0.232 & 0.367 & 0.231 & 0.255 \\
\hline & & $2: 1$ & 0.416 & 0.308 & 0.210 & 0.343 & 0.241 & 0.263 \\
\hline \multirow{8}{*}{$\begin{array}{l}\text { Sewage } \\
\text { sludge } \\
\text { from Łuków }\end{array}$} & $+\mathrm{CaO}$ & $6: 1$ & 0.593 & 0.463 & 0.313 & 0.465 & 0.283 & 0.289 \\
\hline & & $4: 1$ & 0.557 & 0.429 & 0.307 & 0.466 & 0.294 & 0.279 \\
\hline & & $3: 1$ & 0.570 & 0.402 & 0.327 & 0.427 & 0.287 & 0.261 \\
\hline & & $2: 1$ & 0.502 & 0.400 & 0.333 & 0.408 & 0.270 & 0.285 \\
\hline & + ash & $6: 1$ & 0.674 & 0.592 & 0.452 & 0.590 & 0.440 & 0.391 \\
\hline & & $4: 1$ & 0.652 & 0.548 & 0.449 & 0.621 & 0.456 & 0.417 \\
\hline & & $3: 1$ & 0.624 & 0.534 & 0.440 & 0.691 & 0.417 & 0.395 \\
\hline & & $2: 1$ & 0.658 & 0.569 & 0.419 & 0.640 & 0.425 & 0.383 \\
\hline \multicolumn{9}{|c|}{ Mean quantities for $\mathrm{CaO}$ or ash added to sludge } \\
\hline \multirow{4}{*}{\multicolumn{3}{|c|}{$\begin{array}{ll}6: 1 \\
4: 1 \\
3: 1 \\
2: 1\end{array}$}} & 0.499 & 0.419 & 0.303 & 0.428 & 0.300 & 0.292 \\
\hline & & & 0.484 & 0.398 & 0.305 & 0.423 & 0.295 & 0.293 \\
\hline & & & 0.485 & 0.374 & 0.307 & 0.438 & 0.297 & 0.279 \\
\hline & & & 0.472 & 0.378 & 0.295 & 0.411 & 0.307 & 0.290 \\
\hline \multicolumn{3}{|l|}{$\mathrm{LSD}_{0.05}$} & n.s & n.s & n.s & n.s & n.s & n.s \\
\hline \multicolumn{9}{|c|}{ Means for kind of addition to sludge } \\
\hline \multicolumn{3}{|c|}{$\mathrm{CaO}$} & 0.446 & 0.343 & 0.270 & 0.357 & 0.268 & 0.254 \\
\hline \multicolumn{3}{|l|}{ Ash } & 0.524 & 0.441 & 0.335 & 0.493 & 0.332 & 0.323 \\
\hline \multicolumn{3}{|l|}{$\mathrm{LSD}_{0.05}$} & 0.039 & 0.035 & 0.029 & 0.045 & 0.026 & 0.027 \\
\hline \multicolumn{9}{|c|}{ Means for kind of sludge } \\
\hline \multirow{2}{*}{\multicolumn{3}{|c|}{$\begin{array}{l}\text { Sewage sludge from Siedlce } \\
\text { Sewage sludge from Łuków }\end{array}$}} & 0.366 & 0.292 & 0.225 & 0.311 & 0.240 & 0.239 \\
\hline & & & 0.604 & 0.492 & 0.380 & 0.539 & 0.359 & 0.338 \\
\hline \multicolumn{3}{|l|}{$\mathrm{LSD}_{0.05}$} & 0.039 & 0.035 & 0.029 & 0.045 & 0.026 & 0.027 \\
\hline
\end{tabular}

n.s. - differences between average not significant

The obtained study results were subjected to analysis of variance (the Fisher-Snedecor test F), and the $\mathrm{LSD}_{0.05}$ values to compare means were computed using Tukey's test.

\section{RESULTS AND DISCUSSION}

The results show that content of chromium in test plants cultivated in three subsequent years of experiment was higher after application the mixture of sewage sludge with lignite ash than with $\mathrm{CaO}$ (Table 3 ). The content of copper in tested plants cultivated in the first and the second year of the experiment was not significant dependent from kind of addition to the sewage sludge (Table 4). Maize and sunflower harvested in the third year after application of sewage sludge with ash addition contained more copper than in the case when fertilization the mixtures with the participation of $\mathrm{CaO}$ was used. The content of chromium in plants fertilized with sewage sludge without additions most often was higher than their application with $\mathrm{CaO}$ addition and similarly after introduction their mixtures with ash into soil. The content of copper in test plants most often was similar after fertilization with the same sewage sludge, and their mixtures with $\mathrm{CaO}$ and ash. In the studies, a decrease in the contents of the examined heavy metals with increasing amounts of additives $(\mathrm{CaO}$ or ash) to the sewage sludge was 
TABLE 4. The content of copper in test plants $\left(\mathrm{mg} \cdot \mathrm{kg}^{-1} \mathrm{DM}\right)$

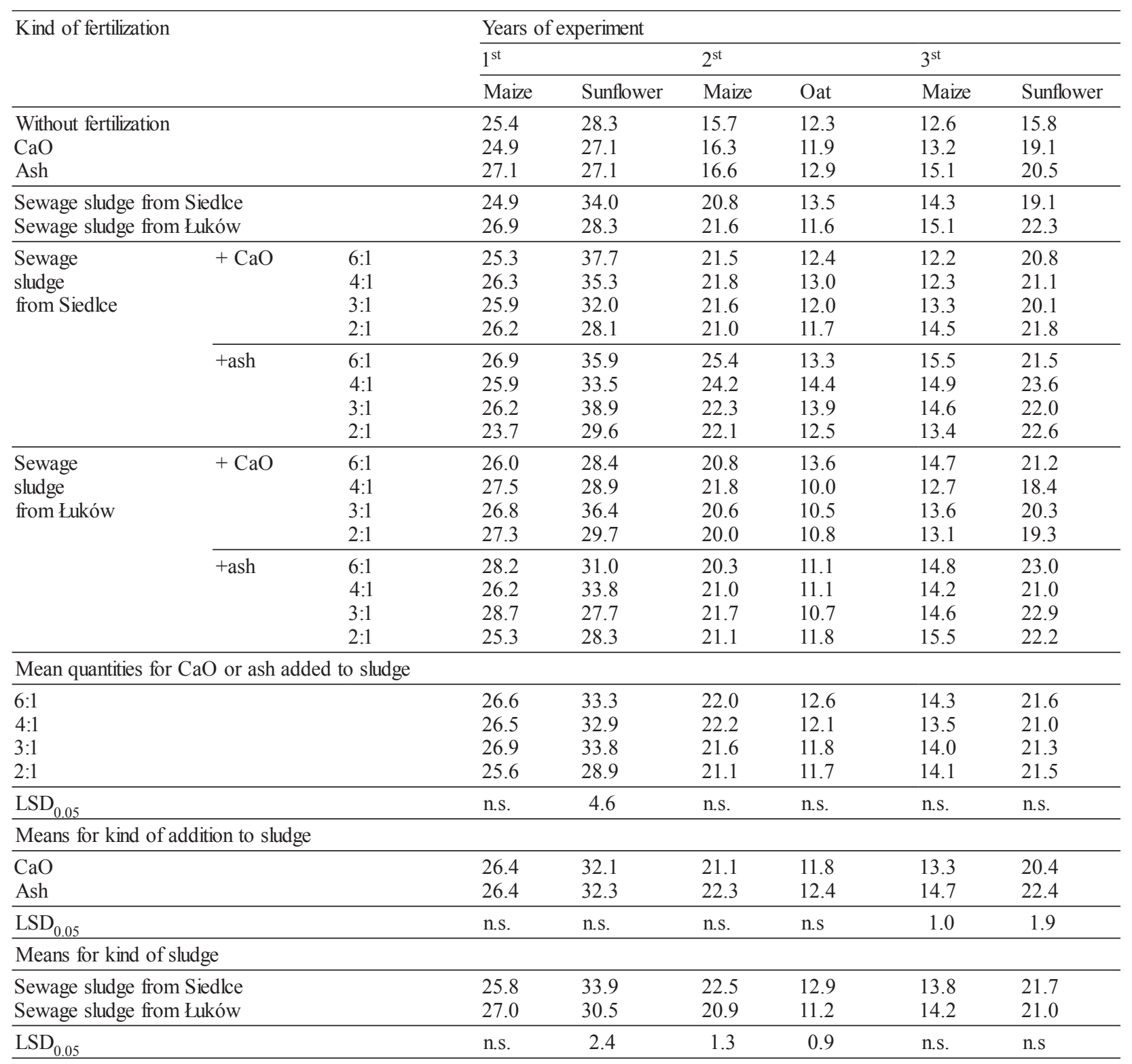

n.s. - differences between average not significant.

observed, but significant differences between mean content were obtained only for the copper in sunflower harvested in the first year following fertilization. Such a relation may result from a systematic increase of $\mathrm{pH}$ in the soil and a decrease in the availability of heavy metals, resulting from the formation of their hydroxides (Gorlach and Gambuś 1991). Alkalisation of the soil after the introduction of the ashes is lower than for introduction of agricultural lime (Saarsalmi and Levula 2007). Therefore, the availability of the studied heavy metals to plants could be higher following the application of the mixtures containing the ash than for the mixtures with $\mathrm{CaO}$.
Particularly large disproportions in the chromium contents in the biomass of the test plants were obtained following the application of mixtures of various types of sewage sludges having originally differentiated chromium contents. Higher content of chromium in plants was obtained after fertilization with mixtures of sewage sludge from Łuków containing more chromium than sludge form Siedlce (Table 2 and 3). Sunflower harvested in the first year, maize and oat cultivated in the second year after fertilization with mixtures of sewage sludge containing more copper (sludge from Siedlce) had higher concentration of that element than after application mixtures with sludge from Łuków 
(Table 2 and 4 ). The content of copper in other plants was not statistically differentiated after application of mixtures of both types of sewage sludge.

The simple correlation coefficients with $\mathrm{r}$ values from +0.951 to +0.762 (Table 6) indicate that for sewage sludge and its mixtures with $\mathrm{CaO}$ and with lignite ash, chromium content in the biomass of the test plants increased with an increasing amount of chromium introduced to soil. Copper contents in the biomass of the studied plants were not significantly correlated with the amount of copper introduced into the soil in the form of sewage sludge and its mixtures. This may be the result of a lack of connection between the amount of soluble forms of copper in the soil and the amount of this element introduced in the form of sewage sludge (Wierzbowska et al. 2016).

The total amounts of chromium and copper taken up by the test plants decreased with an increasing amount of the additive to sewage sludge, but the differences between the ratios $6: 1,4: 1$ and $3: 1$ were not statistically significant (Table 5). Greater amounts of the studied heavy metals were accumulated by the

TABLE 5. The uptake, amount of chromium and copper in sewage sludges and their mixtures remaining in soil, as well as the content of these elements in soil after three years of experiment

\begin{tabular}{|c|c|c|c|c|c|c|c|c|}
\hline \multirow{2}{*}{\multicolumn{3}{|c|}{ Kind of fertilization }} & \multicolumn{2}{|c|}{$\begin{array}{l}\text { The uptake } \\
\text { (sum for } 3 \text { years) } \\
\text { (mg per pot) }\end{array}$} & \multicolumn{2}{|c|}{$\begin{array}{l}\text { The amount remaining } \\
\text { in soil after } 3 \text { years } \\
\text { (mg per pot) }\end{array}$} & \multicolumn{2}{|c|}{$\begin{array}{l}\text { The content in soil } \\
\text { after } 3 \text { years } \\
\left(\mathrm{mg} \cdot \mathrm{kg}^{-1}\right)\end{array}$} \\
\hline & & & $\mathrm{Cr}$ & $\mathrm{Cu}$ & $\mathrm{Cr}$ & $\mathrm{Cu}$ & $\begin{array}{l}\mathrm{Cr} \\
(5.14 *)\end{array}$ & $\begin{array}{l}\mathrm{Cu} \\
\left(5.28^{*}\right)\end{array}$ \\
\hline \multicolumn{3}{|c|}{$\begin{array}{l}\text { Without fertilization } \\
\mathrm{CaO} \\
\mathrm{Ash}\end{array}$} & $\begin{array}{l}0.046 \\
0.029 \\
0.051 \\
\end{array}$ & $\begin{array}{l}3.00 \\
1.93 \\
3.46 \\
\end{array}$ & $\begin{array}{l}- \\
- \\
-\end{array}$ & $\begin{array}{l}- \\
- \\
-\end{array}$ & $\begin{array}{l}4.93 \\
4.86 \\
5.22 \\
\end{array}$ & $\begin{array}{l}4.81 \\
5.16 \\
5.05 \\
\end{array}$ \\
\hline \multicolumn{3}{|c|}{$\begin{array}{l}\text { Sewage sludge from Siedlce } \\
\text { Sewage sludge from Łuków }\end{array}$} & $\begin{array}{l}0.086 \\
0164\end{array}$ & $\begin{array}{l}5.91 \\
6.23 \\
\end{array}$ & $\begin{array}{c}3.98 \\
49.80 \\
\end{array}$ & $\begin{array}{r}12.89 \\
3.21 \\
\end{array}$ & $\begin{array}{r}5.41 \\
10.80 \\
\end{array}$ & $\begin{array}{l}6.47 \\
5.35\end{array}$ \\
\hline \multirow[t]{2}{*}{$\begin{array}{l}\text { Sewage } \\
\text { sludge } \\
\text { from Siedlce }\end{array}$} & $+\mathrm{CaO}$ & $\begin{array}{l}6: 1 \\
4: 1 \\
3: 1 \\
2: 1\end{array}$ & $\begin{array}{l}0.060 \\
0.054 \\
0.051 \\
0.057 \\
\end{array}$ & $\begin{array}{l}4.26 \\
3.91 \\
3.56 \\
4.25\end{array}$ & $\begin{array}{l}3.89 \\
3.84 \\
3.78 \\
3.66 \\
\end{array}$ & $\begin{array}{l}13.96 \\
14.04 \\
14.12 \\
12.92 \\
\end{array}$ & $\begin{array}{l}5.48 \\
5.33 \\
5.40 \\
5.17 \\
\end{array}$ & $\begin{array}{l}6.76 \\
6.65 \\
6.98 \\
6.64 \\
\end{array}$ \\
\hline & +ash & $\begin{array}{l}6: 1 \\
4: 1 \\
3: 1 \\
2: 1\end{array}$ & $\begin{array}{l}0.098 \\
0.086 \\
0.087 \\
0.077 \\
\end{array}$ & $\begin{array}{l}7.44 \\
6.12 \\
6.19 \\
4.76 \\
\end{array}$ & $\begin{array}{l}5.69 \\
6.51 \\
7.31 \\
8.83 \\
\end{array}$ & $\begin{array}{l}11.75 \\
13.25 \\
13.36 \\
15.13 \\
\end{array}$ & $\begin{array}{l}5.64 \\
5.91 \\
5.83 \\
6.13 \\
\end{array}$ & $\begin{array}{l}6.35 \\
6.83 \\
6.57 \\
7.08 \\
\end{array}$ \\
\hline \multirow[t]{2}{*}{$\begin{array}{l}\text { Sewage } \\
\text { sludge } \\
\text { from Łuków }\end{array}$} & $+\mathrm{CaO}$ & $\begin{array}{l}6: 1 \\
4: 1 \\
3: 1 \\
2: 1\end{array}$ & $\begin{array}{l}0.080 \\
0.080 \\
0.078 \\
0.058\end{array}$ & $\begin{array}{l}3.98 \\
4.15 \\
4.06 \\
3.01\end{array}$ & $\begin{array}{l}48.66 \\
48.07 \\
47.50 \\
46.41 \\
\end{array}$ & $\begin{array}{l}5.23 \\
4.96 \\
4.94 \\
5.78\end{array}$ & $\begin{array}{l}11.24 \\
10.96 \\
10.78 \\
11.02 \\
\end{array}$ & $\begin{array}{l}5.73 \\
5.58 \\
5.64 \\
5.92 \\
\end{array}$ \\
\hline & + ash & $\begin{array}{l}6: 1 \\
4: 1 \\
3: 1 \\
2: 1\end{array}$ & $\begin{array}{l}0.142 \\
0.147 \\
0.134 \\
0.103\end{array}$ & $\begin{array}{l}5.66 \\
5.75 \\
5.74 \\
4.17 \\
\end{array}$ & $\begin{array}{l}50.06 \\
50.16 \\
50.30 \\
50.55\end{array}$ & $\begin{array}{l}4.32 \\
4.48 \\
4.74 \\
6.79 \\
\end{array}$ & $\begin{array}{l}11.42 \\
11.46 \\
11.33 \\
11.61 \\
\end{array}$ & $\begin{array}{l}5.58 \\
5.51 \\
5.76 \\
6.05 \\
\end{array}$ \\
\hline \multicolumn{9}{|c|}{ Mean quantities for $\mathrm{CaO}$ or ash added to sludge } \\
\hline \multicolumn{3}{|l|}{$\begin{array}{l}6: 1 \\
4: 1 \\
3: 1 \\
2: 1 \\
\end{array}$} & $\begin{array}{l}0.095 \\
0.092 \\
0.088 \\
0.074 \\
\end{array}$ & $\begin{array}{l}5.34 \\
4.98 \\
4.89 \\
4.05 \\
\end{array}$ & $\begin{array}{l}27.08 \\
27.15 \\
27.22 \\
27.36 \\
\end{array}$ & $\begin{array}{r}8.82 \\
9.18 \\
9.29 \\
10.16 \\
\end{array}$ & $\begin{array}{l}8.45 \\
8.42 \\
8.34 \\
8.48 \\
\end{array}$ & $\begin{array}{l}6.11 \\
6.14 \\
6.24 \\
6.42 \\
\end{array}$ \\
\hline \multicolumn{3}{|l|}{$\mathrm{LSD}_{0.05}$} & 0.013 & 0.70 & n.i. & n.i. & n.i. & n.i. \\
\hline \multicolumn{9}{|c|}{ Means for kind of addition to sludge } \\
\hline & Ash & $\begin{array}{l}0.065 \\
0.109\end{array}$ & $\begin{array}{l}3.90 \\
5.73\end{array}$ & $\begin{array}{l}25.73 \\
28.68\end{array}$ & $\begin{array}{l}9.49 \\
9.23\end{array}$ & $\begin{array}{l}8.17 \\
8.67\end{array}$ & $\begin{array}{l}6.24 \\
6.22 \\
\end{array}$ \\
\hline \multicolumn{3}{|l|}{$\mathrm{LSD}_{0.05}$} & 0.007 & 0.37 & 2.71 & n.i. & n.i. & n.i. \\
\hline \multicolumn{9}{|c|}{ Means for kind of sludge } \\
\hline \multicolumn{3}{|c|}{$\begin{array}{l}\text { Sewage sludge from Siedlce } \\
\text { Sewage sludge from Łuków }\end{array}$} & $\begin{array}{l}0.071 \\
0.103\end{array}$ & $\begin{array}{l}5.06 \\
4.57\end{array}$ & $\begin{array}{c}5.44 \\
48.96\end{array}$ & $\begin{array}{r}13.57 \\
5.16\end{array}$ & $\begin{array}{r}5.61 \\
11.23\end{array}$ & $\begin{array}{l}6.73 \\
5.72\end{array}$ \\
\hline \multicolumn{3}{|c|}{$\mathrm{LSD}_{0.05}$} & 0.007 & 0.37 & 2.71 & 0.84 & 0.68 & 0.51 \\
\hline
\end{tabular}

* chromium and copper content in soil before foundation of experiment. 
TABLE 6. The value of simple correlation coefficient (r) between selected parameters

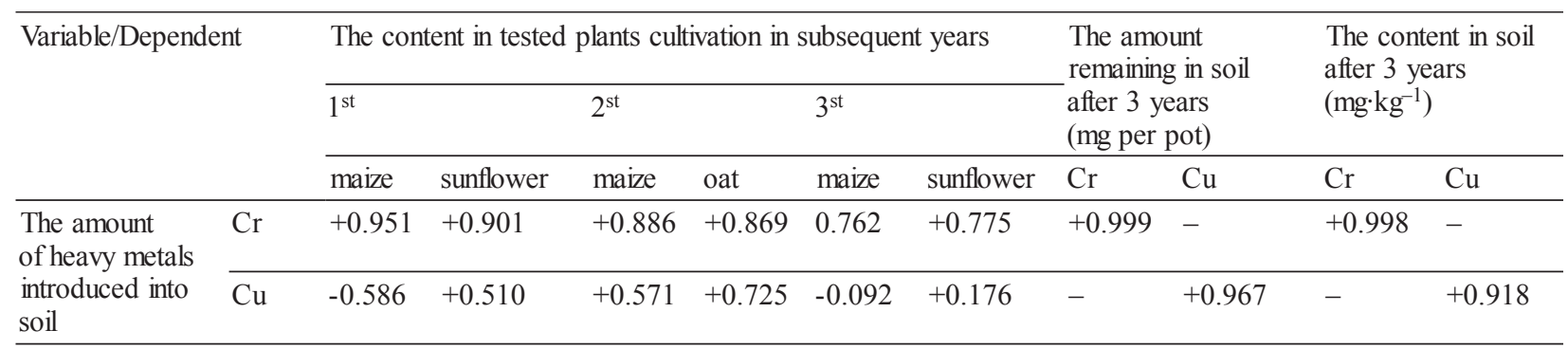

test plants fertilized with mixtures of sewage sludge with ash than with $\mathrm{CaO}$. A greater amount of chromium and a smaller amount of copper were taken up by the test plants fertilized with sewage sludge from Łuków than with sludge from Siedlce. The same relation was obtained for the contents of chromium and copper in the soil and their amounts remaining in the soil, as a result of fertilisation with sewage sludge. The contents of studied heavy metals in the soil did not significantly depend on the types and amounts of the used additives to sewage sludge. Compared to the contents of chromium and copper in the soil before the experiment, after 3 years of cultivation, the copper content following the application of both types of sewage sludges and their mixtures and the chromium content following the application of sewage sludge from Siedlce, were somewhat higher. Following the application of the mixtures of sewage sludge from Łuków, the chromium content in soil was more than twice higher than before the experiment. A significant correlation was found between the amounts of chromium and copper introduced into soil and their contents in soil after completion of the study (the simple correlation coefficient values were $r=+0.998$ and $r=+0.918$, respectively). The accumulation of heavy metals in soil following the application of sewage sludge, increasing with increasing doses of the sludge, is a phenomenon reported in many studies (e.g. Jezierska-Tys and Frąc 2008, Wołejko et al. 2013). Contamination of soil with heavy metals, resulting from application of sewage sludge, may be limited by adding substances with lower contents of heavy metals to the sludge (Rutkowska et al. 2004).

Assessment of the effect of fertilisation on the contents of heavy metals in soil together with the changes in their concentrations may be supplemented by a comparison with the standards defining a degree of soil contamination (e.g. with heavy metals) at which none of the functions fulfilled by soil is disturbed (Ustawa - Prawo Ochrony Środowiska 2001). The lands classified as agricultural (excluding lands under ponds and ditches) should contain no more than 150 $\mathrm{mg}$ of both chromium and copper in $1 \mathrm{~kg}$ DM of the 0-30 cm soil layer (Rozporządzenie Ministra Śro- dowiska 2002). The contents of the studied heavy metals in soil fertilized with the studied sewage sludge and their mixtures with $\mathrm{CaO}$ or with lignite ash after 3 years of the experiment were much lower than the above-mentioned contents.

\section{CONCLUSIONS}

1. The content of chromium in test plants (maize, sunflower and oat) was higher after application of mixture of sewage sludge with lignite ash than with $\mathrm{CaO}$. Copper concentration in these plants was similar after application sewage sludge and their mixtures with $\mathrm{CaO}$ and lignite ash.

2. Differentiation of amounts of additives $(\mathrm{CaO}$ or ash) to the sewage sludge most often did not significantly impact the content of chromium and copper in test plants and soil.

3. The uptake of chromium and copper by test plants (sum for 3 years) was higher after application of sewage sludge with addition of lignite ash than in the mixture with $\mathrm{CaO}$. The amount of these elements taken up by the cultivated plants decreased with increasing of quantity additives ( $\mathrm{CaO}$ and ash) to the sewage sludge.

4. The fertilization with mixture of sewage sludge with $\mathrm{CaO}$ or ash caused similar increase in the content of chromium and copper in soil, but their concentration after single application of these mixtures remained on a permissible level according to the standards presented in Minister of Environment Regulation (Rozporządzenie Ministra Środowiska z dnia 09 września 2002).

\section{REFERENCES}

Basu M., Pande M., Phadoria P.B.S., Mahapatra S.C., 2009. Potential fly-ash utilization in agriculture: A global review. Progress in Natural Science 19: 1173-1186.

Czekała J., Jakubus M., Mocek A., 2002. Selected properties of sewage sludge from sewage treatments plants in Wielkopolska. Part III. Heavy metals and polycycling aromatic hydrocarbons. Acta Agrophysica 70: 91-98 (in Polish). 
Gadepalle V.P., Ouki S.K., Herwijnen R., Hutchings T., 2008. Effects of amended compost on mobility and uptake of arsenic by rye grass in contaminated soil. Chemosphere 72: 10561061.

Gorlach E., Gambuś F., 1991. The effect of liming adding peat, and phosphorus fertilization on uptake of heavy metals by plants. Polish Journal of Soil Sciences 24/2: 199-204.

Grzywnowicz I., Strutyński J., 2000. Agricultural use of sewage sludge as a source of soil contamination with heavy metals. Advances of Agricultural Sciences Problem Issues 472: 297 304 (in Polish).

Hooda P.S., Alloway B.J., 1994. Changes in operational fractions of trace metals in two soils during two - years of reaction time following sewage sludge treatment. International Journal of Environmental Analytical Chemistry 57: 289-311.

Jakubas M., Czekała J., 2001. Heavy metal speciation in sewage sludge. Polish Journal of Environmental Studies 10(4): 245250.

Jezierska-Tys S., Frąc M., 2008. Influence of fertilization with dairy sewage sludge sanitised with coal fly ash on microbiological activity and concentration of heavy metals in greybrown podzolic soil. Journal of Elementology 13(4): 535544.

Polish Soil Classification (Systematyka Gleb Polski), 2011. Roczniki Gleboznawcze - Soil Science Annual 62(3): 1-193 (in Polish with English summary).

Rosik-Dulewska C., 2000. Sanitation of wastewater sludge with mineral wastes as metals speciation forms. Archives of Environmental Protection 26(3): 29-42.

Rosik-Dulewska C., 2001. Heavy metals and their fractions in sewage sludge sanitized using lignite ash. Advances of Agricultural Sciences Problem Issues 475: 349-356.

Rozporządzenie Ministra Środowiska z dnia 09 września 2002 r. w sprawie standardów jakości gleby oraz standardów jakości ziemi (Dz.U. 2002, nr 165, poz. 1359).

Rutkowska B., Szulc W., Łabętowicz J., 2004. Soil environment hazard evaluation under condition of immission of heavy metals contained in the municipal sewage sludge. Soil Science Annual 55(1): 203-208.
Saarsalmi A., Levula T., 2007. Wood Ash Application and Liming: Effects on Soil Chemical Properties and Growth of Scots Pine Transplants. Baltic Forestry 13(2): 149-157.

Sanerbeck D.R., 1991. Plant, element and soil properties governing uptake and availability of heavy metals derived from sewage sludge. Water Air Soil Pollution 57/58: 227-237.

Singh R.P., Agrawal M., 2008. Potential benefits and risks of land application of sewage sludge. Waste Management 28(2): 347-358.

Smith S.R., 1996. Agricultural Recycling of Sewage Sludge and the Environment. CAB International: pp. 382.

Tiruneh A.T., Fadiran A.O., Mtshali J.S., 2014. Evaluation of the risk of heavy metals in sewage sludge intended for agricultural application in Swaziland. International Journal of Environmental Sciences 5(1): 197-216. doi: 10.6088/ijes.2014050100017.

Usman K., Khan S., Ghulam S., Khan M.U., Khan N., Khan M.A., Khalil S.K., 2012. Sewage Sludge: An Important Biological Resource for Sustainable Agriculture and Its Environmental Implications. America Journal of Plant Sciences 3: 1708-1721, doi.org/10.4236/ajps.2012.312209

Ustawa z dnia 27 kwietnia $2001 \mathrm{r}$. Prawo ochrony środowiska (tekst jedn.: Dz.U. 2013, poz. 1232 z późn. zm.).

Wierzbowska J., Sienkiewicz S., Krzebietke S., Sternik P., 2016. Content of selected heavy metals in soil and in Virginia mallow (Sida hermaphrodita) fertilised with sewage sludge. Journal of Elementology 21(1): 247-258 doi: $10.5601 /$ jelem.2015.20.3.975

Wołejko E., Wydro U., Butarewicz A., Łoboda T., 2013. Effects of sewage sludge on the accumulation of heavy metals in soil and in mixtures of lawn grasses. Environment Protection Engineering 39(2): 67-76. doi: 10.5277/EPE130207

Yilmaz D.D., Temizgul A., 2012. Assessment of arsenic and selenium concentration with chlorophyll contents of sugar beet (Beta vulgaris var. saccharifera) and wheat (Triticumaestivum) exposed to municipal sewage sludge doses. Water Air Soil Pollution 223: 3057-3066.

Received: May 4, 2016

Accepted: July 29, 2016

\section{Zawartość chromu i miedzi w roślinach i glebie nawożonej osadami ściekowymi z dodatkiem różnych ilości $\mathrm{CaO}$ lub popiołu z węgla brunatnego}

Streszczenie: $\mathrm{W}$ doświadczeniu wazonowym badano wpływ nawożenia świeżymi mieszaninami osadów ściekowych z tlenkiem wapnia $(\mathrm{CaO})$ lub z popiołem z węla brunatnego w proporcjach suchej masy 6:1, 4:1, 3:1 i 2:1 na zawartość chromu i miedzi w roślinach i w glebie. Osady ściekowe pobrano z oczyszczalni ścieków w Siedlcach (osady po metanowej fermentacji) i w Łukowie (osady stabilizowane w warunkach tlenowych). Zawartość chromu w biomasie roślin testowych była większa po zastosowaniu mieszanin osadów ściekowych z popiołem niż z CaO. Zawartość miedzi w roślinach najcześciej nie była istotnie uzależniona od rodzaju dodatku do osadów. Zróżnicowane ilości dodatków do osadów ściekowych nie wpłynęły istotnie na zawartość obydwu badanych metali ciężkich w roślinach. Zawartość chromu i miedzi w glebie po 3 latach uprawy roślin była większa niż przed założeniem doświadczenia, ale nie była istotnie zróżnicowana w zależności od rodzaju oraz ilości zastosowanego dodatku do osadów ściekowych.

Słowa kluczowe: osady ściekowe, tlenek wapnia, popiół z węgla brunatnego, chrom, miedź 